\title{
HID ランプ用照明器具
}

\section{1. ま えがき}

昨年より今年にかけて販売された 53 年度排ガス 規制 車は, 前年度のモデルより然料消費率が向上し, それが 強力なセールスポイントとなっている.そしてユーザも その経済性と省エネルギー效果を理解している.しかし われわれの照明分野では，なぜかそれが理解されていな い.

自動車で $\mathrm{km} / 1$ を理解して車種を選定しているのに, 照明設備では, $1 \mathrm{~m} / \mathrm{W}$ が理解されていないのか，これは 何もコーザ側の責任ではなく，䊞品を供給するメ一カ側 の努力が不足していると思ら。照明に対して, 現在まで 省エネルギー刘策として実施されたことは，点灯中止， 間引き点灯，点灯時間の短維などの節約による省上ネル ギーが主体であり，技術レベルでの省エネルギーは光源 が主体であり，機器を含めたトータルシステムとしての アプローチは少ない.

そこで，今回，HID ランプ用照明器具に対して，節 約レベルではなく，新技術による省エネルギーのための アプローチを試み商品化に成功したので，二，三の例を 含めて，この問題を考察し結果を報告する.

\section{2. 省エネルギーのための基本式}

照明施設の省エネルギーの二大要素は, 灯数 $(N)$ と 点灯時間 $(\mathrm{H})$ である.これをいかに削減するかにより 省エネルギーの効果が決をる. 照明器具側から見れば, 灯数 $(N)$ をいかに削減するかが課題となる。

その基本式は次式が考えられる。

$$
N=\frac{E \cdot A}{F \cdot U \cdot M}
$$

$$
\begin{array}{ll}
E: \text { 平均照度 } & A: \text { 照明面程 } \\
F: \text { ランプ光束 } & U: \text { 照明率 }
\end{array}
$$

$M:$ 保守率

\section{専門会員 西野 純一郎*}

これは何も新しい式ではなく，照明を実施するものが 每日使用している計算式であり, この式をいかに理解し て，省エネルギー対策を計画し，商品計画ならびに照明 設計を実施しているかが，最も重要なことである.

この式から理解できることは

（1） $N$ (灯数)， H (点灯時間)を減少すれば省エ ネ ルギーになることは容易に気がつく，次に気づくこと は,

（2）分子の $E$ (照度) と $A$ (照明面積) を小さくする ことであり，照度低下や照明する場所を制限することで ある。しかし，これらは節約による省エネルギーのこと であり，芷に行政側の仕本である。技術側の仕事として は，少ないッネルギ一で最大の効果を焱籍さすことであ り,

（3）分卌の值を大にすることにより，灯数 $(N)$ ，す なわち，電力が测減できることになる。これが今回，提 案する省エネルギーのための HID ランプ用照明器具側 からのアプローチであり，FFUM の技術開発」である.

\section{FUM の問題点}

\section{1 ランプと照明器具の効率}

最近の HID ランプは，その改良研究が進み，高効辫 で長寿命の方向に進み，その中でも高压ナトリウムラン プは，省エネルギーの効果が多大であると認められてい る.

これは一見正解のようであるが，注意すべきことは， ランプ単体で比較した場合のことであり，どの照明施設 をみても, HID 光源を照明器具なしで裸点灯している ところは見当たらない。ランフと組み合わされる機器類 （照明器具，安定器）と照明設就が，常にマッチングし て初めて達成されることである。

表 1 は，その具体例を示したもので，スポーツ照明 などに使用されている狄角形配光の投光器に, 各種 HID ランプを使用したときのランプ光束と，器具性能を比較 したものであるが，この結果が示すように，ランプの効 
表 1 ランプと照明器具の効率

\begin{tabular}{|c|c|c|c|c|c|}
\hline \multirow[b]{2}{*}{ シンプ形式 } & \multicolumn{2}{|c|}{ ランプ特性 } & \multicolumn{3}{|c|}{ 投 光 器 特 性: } \\
\hline & $\begin{array}{c}\text { ランプ光 } \\
(\operatorname{lm})\end{array}$ & 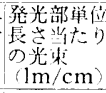 & 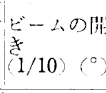 & $\begin{array}{c}\qquad \begin{array}{c}-\alpha \\
(\%)\end{array} \\
(\%)\end{array}$ & $\begin{array}{l}25^{\circ} \text { (0) } \\
\text { 光束 } \\
\quad(\operatorname{lm})\end{array}$ \\
\hline $\mathrm{NH} 400$ & 46,000 & 517 & 25.5 & 30.6 & 13,846 \\
\hline M 400 & 35,000 & 778 & 21.5 & 34.2 & 13,020 \\
\hline H 400 & 21,000 & 309 & 23. 5 & 29.4 & 6,498 \\
\hline
\end{tabular}

率と照明器具のビーム効率は一致せず, さらに, この值 を用いて光束法で単純に照明設計した場合などは, 高些 ナトリウムランプとメタルハライドランブは，ほ泳同じ 灯数となり，省エネルギー効果が出ないことになる。こ の原因は, 照明器具の光学系と光源サイズがマッチング せず，さらに照明設計手法も不適当なことにより生じた ことである。

\section{2 照明器具の機能と用途 (UMの問題点)}

照明器具の機能を分類すると表 2 となる. この中で 何が重要かは用途，目的により異なる。省エネルギーの ためには経済性が厦先されるが，照明システムである以 上, 光の量的なものを中心として，全体的なバランスが とれていなければ真の省ェネルギーとはならない。

表 2 照明斝具とそのシステムの機能

\begin{tabular}{|c|c|c|}
\hline 区 & 分 & 内 \\
\hline \multirow{2}{*}{ 光学䊁性: } & int的 & 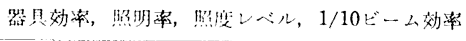 \\
\hline & 教的 & 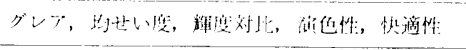 \\
\hline 耐 久 & ll: & 寿余, 耐候件, 耐食件, 光束維持率 \\
\hline 安 全 & 性: & 沵度，电父䋓縁件 \\
\hline 便 前 & 性 & 保守，取付计配線，ランプ交撸 \\
\hline 和周 & 珄 & 形状寸泣，色彩，重量，デザイン \\
\hline 経 済 & 性: & 電力消費显, 設備費, 保守費 \\
\hline
\end{tabular}

効率を優先するあまり

（1）器具効率は高いが照明率が偠く，またグレアが大 で見え方を恶くする製品

(2) グレアは少ないが，器具効率が 20〜50\%と低く， 灯数が増加する製品

（3）設置当初は照度が㙜いが，すぐに反射率が低下し 照度不足となるため，保守率を低くとらなければならな い製品

（4）設㑲費は安価であるが，電力費，保守費などのラ ンニングュストがかかり，トータル的な経済性がない製 品

（5）製品のデザインは良いが，効率が低く，また持命 の短い製品などは，トータル的な照明機能のバランスが とれていないシステムであり，省ェネルギー，省資源， 省力化と逆行するものであり，今後，技術改善しなけれ ばならない事項である。

\section{4. 省エネルギーの具体策（FUM の技術開発）}

\section{1 目的, 用途別に適した配光の開発と標準化 (U の技術的アプローチ)}

照明器具の配光性能は, その照明する空間と光の最・ 質ならびに経済州のバランスを考虙することが必装で ある。このよらな総合的な慓準化作業としては，眧和 45 年に日本照明器具工寀会で「道路照明設備の標準化㸴 究」が実施され, 現在幹線道路にはその照明器具が使用 されている，この研究では，光の量と質は確保されてい るが，エネルギー危機が発生する以前の呼究であり, 現 在の省エネルギー形の HID 光源を含めて見值す段階に きていると思ら。これ以外の分野では, トンネル照明な どがあり，他の施設では，システム的な研究も少なく， 照明器具もすべての用途を考虑した方能形で, 省ェネル ギーの効果は少ない.

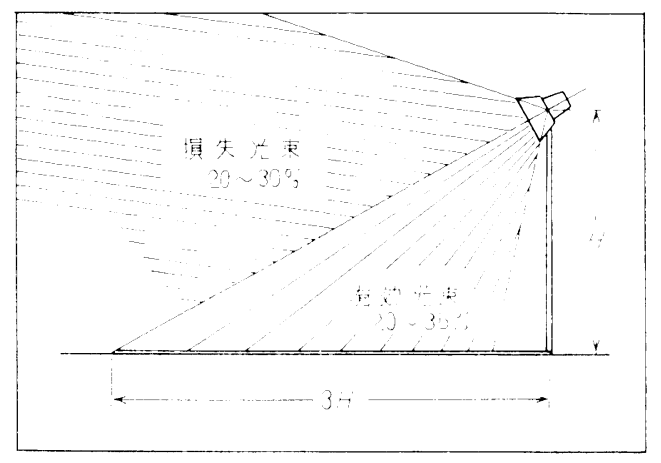

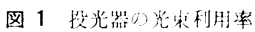

たと光ば，投光器を使用して屋外の駐車場，スボーツ 施設などを $\mathrm{B} / \mathrm{H}=2$ 〜 3 で照朋した場合, 図 1 のよう に光中心軸より上方向の斜線で示す部分の光は, 大部分 損失光となり，器具効率 60 70\%の製品を使用しても， 有効に利用できる光束は 20 ３5\%で，設圈灯数を增す ことにより，所要照度を確保している状態であり，省エ ネルギーとは逆行するものである.

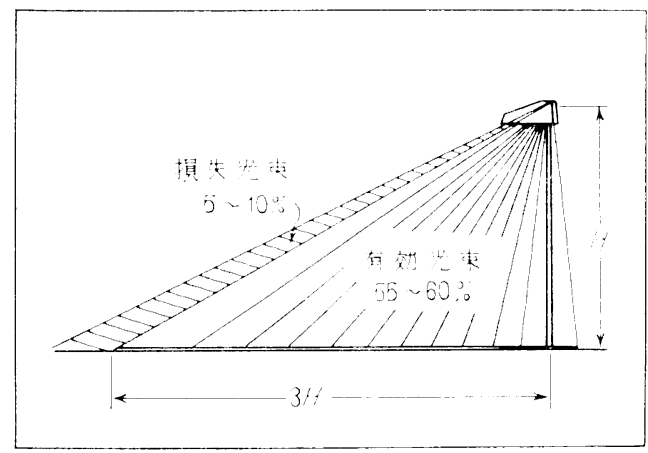

図 2 節電形器具での光束利用率 


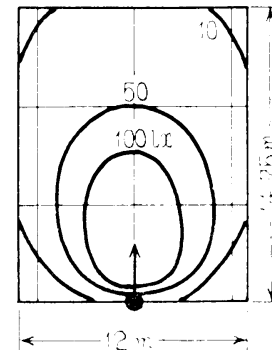

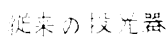

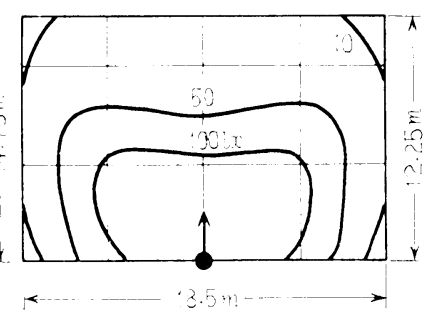

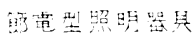

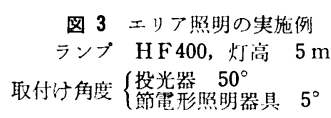

これを図 2 のような, 節電形の光学系を採用した照 明器具を開発すると, グラウンド面に達する光は 55〜 60 \%にも達する。両者の水平面照度を比較すると図 3 と なる．この四中の $10 \mathrm{~lx}$ 以上の照射面積は

従来の投光器による照明 $177 \mathrm{~m}^{2}$

節電形の照明器具による照明 $227 \mathrm{~m}^{2}$ となる。

これは屋外のェリア照明の一例でするが，他の分野で も，光怗利用率むたは照明率の高いHID 哭具を開発 し，その照明システムを標準化与れば 20〜 40\%の省工 ホルギーが見认めると宁测する。

\section{2 光学系の CAD による最適設計 (FU の技術的ア プローチ)}

現在, 光学系 (反射・跳折系) の設叶は笔算機の利用 が可能な段階にきている，CAD のねらいは，設計武作 段階の時間と費用を削減でさるマネジメントに対しての 利用もあるが，最大のねらいは最適設㖕を導き出すこと にある。目的を省エネルギーにしぼった場合，その応用 は無限にあり，ランプと反射系の諸小法ならびに特性な どの変数を組み合わせて，1\%でも多くの光束を制御し て有効活用を計ることである。従来の CAD によらない 経験的な設計法では, シビヤな配光の制御がすずかし く, 器具の性能を器具効率を主体にして評価していた が，これでは真の性能を示していない場合が多い，CAD では経済的な見地より，器具のサイズと使用光源を選定 すれば，器具効率の上限值は，電算機により容易に見つ けることができるため，設計作業の中心は，省エネルギ 一のために照明エリア（1/2 照度牦内，1/10 ビーム内な

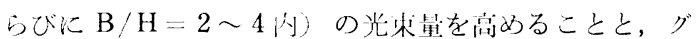
レアなどの光の質的性能がどれだけ向上するかが，評伴 の基準となり性能を定めることとなる.

このアプローチを屋队天非灯の反射がさで尖施する と表 3 ならびに図 4 の值となり, 径来の常裁をやぶっ

\begin{tabular}{|c|c|c|c|}
\hline & 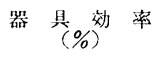 & $\begin{array}{l}60^{\circ} \text { 以上のグレア } \\
\text { となる光束 }(\%)\end{array}$ & $\begin{array}{l}60^{\circ} \text { 以内の有効な } \\
\text { 光束 }(\%)\end{array}$ \\
\hline 街 束 形 & 74 & 12 & 62 \\
\hline 程形 & 78 & 5 & 73 \\
\hline
\end{tabular}
た高効率でグレアレスの光の量と質の両面其，俸れた性

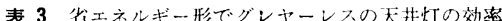

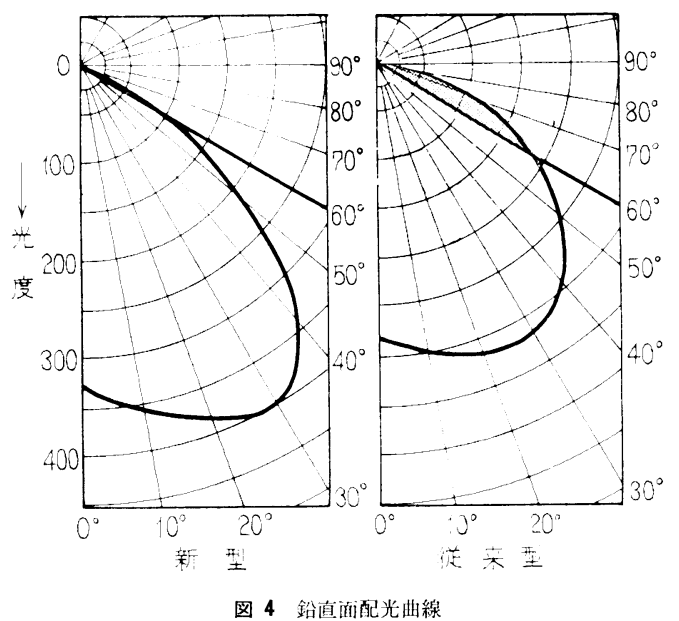

能を持った商品も開発可能となる。

\section{3 高効率を維持できる新材料の 開 発（Mの技術的 アプローチ）}

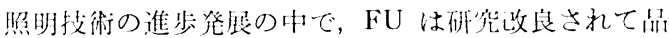
貿州能は问上してきているが， $M$ (保等率)については ランンの長寿命化が上体であり，機器側よりの技術的つ ブーチは少ない。をた照明のソフト側に扔いても，保 摔に对しては，減光補傎的な設咕に余裕をもたせるた めの安全係数としての考方方が強く，乙かもこの値は一 般的には $0.8 \sim 0.5$ の值が照明設計時に採用されている. 省エネルギーの立場からすれば，この值は $1.25 〜 2.0$ 倍 の余分な電力を点灯初期に見込んでいることになり，今 後，保守率の技術レベルでの改善は省エネルギーのため の最重要課題であり, 対策の施していない照明器具は, エネルギー浪費形の過去の商品となるであろら。

改善のアプローチには二つの方法がある。第 1 はラン ブが寿命末期までハロゲン電球のように減光せず，光束 が一定に維持できることである。これにはランプ自身の 改善と，回路的にランプ動程をコントロールすることで あり, 今後の研究棵連である。

第2 2 の方法は，すで技術開発され防品化されてい る。こ扎は反射鏡の表面保港膜を従来の陽極酸化皮膜 （アルマイト類）から而食・耐薬品性，ならびに平消性: の㑃れているけい酸ガラス被膜（アルグラス）光を施す 万法で，父射鏡内面の腐食と污損による反射率の低下を 防ぐために効果的である.たと艺表 4 に耐蒋品性の 比較を示す。ささに大父污染の激しい工場地带や大都市 
表 4 アルミ三ウム保護被膜の耐浆品件比較

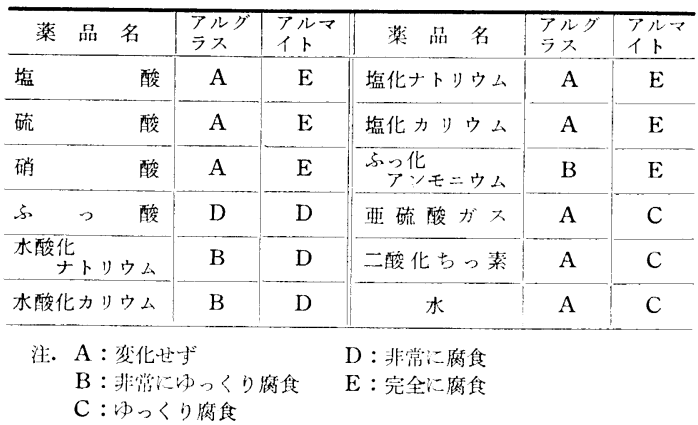

では，照明器具を密閉形にしてランプ消灯時に吸入する 大父污染物留の $\mathrm{NOx}, \mathrm{SO}_{2}$ などの腐食ガスや, 数ミクロ ンの麼埃を吸着さす活州炭のフィルタを取り付汁，照明 器具の光源公以部の反射鏡面を常にクリーンにする方法 がある。

この効果の一例を 図 5 に小㳡.

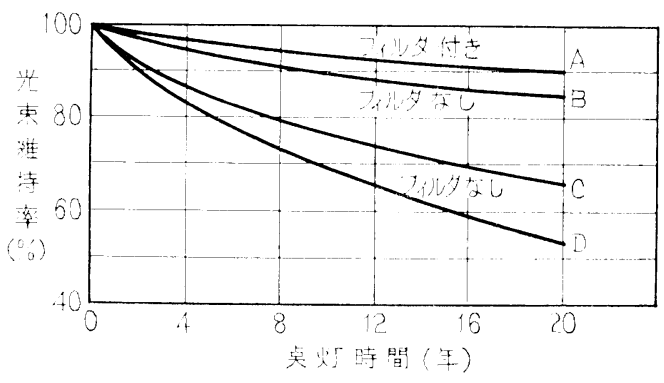

図 5 フイル夕付き照明器具の光束維持率 (ランプ減光恃含まない)

注 A : ランプ交換时 (4 年ごと)に乾いた布でグローブの $\mathrm{D}$ 外面在家了

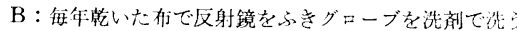

C : ランプ交换時（4 年ごと）反射鏡を乾いた布でふき グローブを沈剂で洗う

\section{5. 省エネルギー形照明器具による節電効果}

FUM の技術改率を施した照明器具を使用して，HID
表 5 省エネルギー形ンステムの経済比較

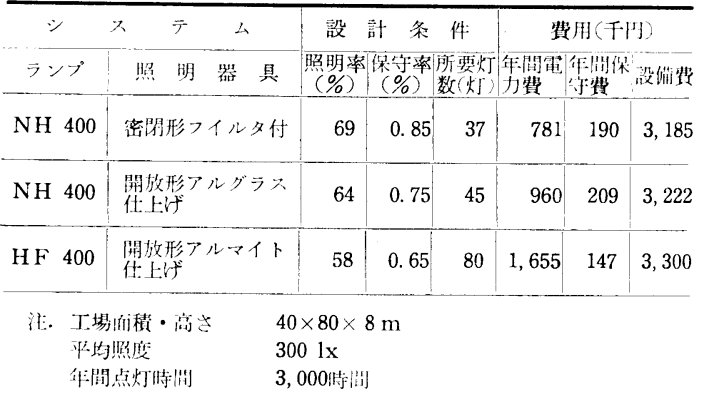

ランプ中最も効率の高い高正ナトりウムランプを用いた ときの経济比較を工場照明で行ならと表 5 となりけ い光高压水銀ランプの照时手法より，年間 100 万円近い 省電力となり，さらに特篗すずきことは，FUM を施し た照明器具を使用しても設備费は，従来の照明設借と同 等またはそれ以下であることである。

\section{6. あ と がき}

HID 照明器具から, 省エネルギーのための提案を節 約レベルではなく，技術レベルから試み，FUM の具体 策を報告したが，これらは古べて新テクノロジーであ り，設備費は彷来と同等またはそれ以下で，照明の質を 向上させて, 数十パーもントの省エネルギーを可能にし たことが特長である.

今後これらの提案をべースにして，この照明方式を普 及さすために，照明のソフトとハードの標準化と省エネ ルギーのための新技術をさらに開発したい。

\section{参考文 献}

(1) 村本：珪酸皮膜のアルミニウム反射鏡への利用 昭51照明学会全国大会

（受付 1977 年 12 月 2 日） 